\title{
DISTRIBUSI SPASIAL, STATUS PEMANFAATAN, DAN UPAYA KONSERVASI PESUT MAHAKAM (Orcaella brevirostris) DI KALIMANTAN TIMUR
}

\author{
Dharmadi'), Dede Irving Hartoto'), Syahroma Husni Nasution²), dan Dian Oktaviani') \\ 1) Peneliti pada Pusat Riset Perikanan Tangkap, Ancol-Jakarta \\ 2) Peneliti pada Pusat Penelitian Limnologi-Lembaga IImu Pengetahuan Indonesia, Cibinong-Bogor \\ Teregistrasi I tanggal: 1 April 2008; Diterima setelah perbaikan tanggal: 18 Juli 2008; \\ Disetujui terbit tanggal: 6 Oktober 2008
}

\begin{abstract}
ABSTRAK
Penelitian dilakukan pada tahun 2004 - 2006 di Danau Semayang dan Muara Kaman (bagian dari Sungai Mahakam), Kalimantan Timur, melalui survei lapangan dan wawancara langsung dengan nelayan, masyarakat, dan Dinas Perikanan, Dinas Perlindungan Hutan dan Pelestarian Alam. Tujuan penelitian ini adalah untuk mengetahui penyebaran secara spasial, status pemanfaatan, dan upaya konservasi pesut Mahakam (Orcaella brevirostris). Hasil pengamatan menunjukkan bahwa distribusi pesut Mahakam secara spasial terdapat di Muara Kaman, Muara Sungai Pela Kecil, muara Sungai Pela Besar, Danau Semayang, dan Danau Melintang. Pada saat ini, pesut Mahakam di Sungai Mahakam digunakan sebagai wisata air bagi turis domestik maupun luar negeri. Upaya konservasi pesut Mahakan dapat dilakukan melalui perlindungan habitat dari pencemaran dan pendangkalan, perlindungan suaka perikanan yang berfungsi untuk penyedia makanan alami serta meningkatkan peran aktif masyarakat agar turut menjaga kelestarian pesut.
\end{abstract}

KATAKUNCI: distribusi spasial, status pemanfaatan, konservasi, pesut Mahakam, Kalimantan Timur

ABSTRACT: Spasial distribution, utilization status, and conservation of Mahakam Dolphin (Orcaella brevirostris) of East Kalimantan. By: Dharmadi, Dede Irving Hartoto, Syahroma Husni Nasution, and Dian Oktaviani

This study was conducted during 2004 to 2006 in Semayang and Melintang Lakes, Mahakam segment around Muara Kaman River of East Kalimantan, through field survey methods, and directly interview to respective respondens of fishers, local people, Fisheries Regency Departement and Forest Protection and Natural Resources Conservation. The objective of the study was to elucidate the distribution spasial, utilization status, and conservation effort of freshwater dolphin (Orcaella brevirostris). Results show that the spasial distributions of freshwater dolphin were found in Kaman, Pela Kecil, Bank of Pela Besar Rivers, Semayang, and Melintang Lakes. Freshwater dolphines was used as echotourism for local and foreign tourisms. There are some efforts to conserve of freshwater dolphin in the East Kalimantan, namely habitat protection from pollution and sedimentation, fisheries area protection for providing natural food and to increase local people role in conserving the existence of these animals.

\section{KEYWORDS: $\quad$ spasial distribution, utilization status, conservation, Mahakam dolphin, East} Kalimantan

\section{PENDAHULUAN}

Pada umumnya mamalia air seperti lumba-lumba dan ikan paus hidup di laut, tetapi pesut (Orcaella brevirostris) hidup di sungai-sungai daerah tropis. Populasi satwa langka yang dilindungi UndangUndang sejak tahun 1999 ini hanya terdapat di tiga lokasi di dunia yaitu Sungai Mahakam, Mekong, dan Irawady (Anonimus, 1999). Pada tahun 1970, pesut sering ditemukan di banyak muara-muara sungai di Kalimantan, tetapi sekarang pesut menjadi satwa langka. Kecuali di Sungai Mahakam, di tempat ini habitat pesut Mahakam dapat ditemukan ratusan kilometer dari lautan yaitu di wilayah Kecamatan Kota Bangun, Kabupaten Kutai Kartanegara, Kalimantan Timur. Habitat hewan pemangsa ikan dan udang air tawar ini dapat dijumpai di perairan Sungai Mahakam, Danau Jempang, Danau Semayang, dan Danau Melintang (www.kutaikartanegara.com/pesut.html./12 Januari 2008).

Pesut air tawar (river do/phin) merupakan mamalia air yang dalam kategori IUCN termasuk dalam daftar merah dengan status hampir punah - critically endangered (Kreb \& Budiono dalam Kreb, 2004). Hal ini karena populasinya cenderung mengalami 
penurunan dari waktu ke waktu. Kerusakkan habitat merupakan salah satu faktor yang dapat menyebabkan penurunan populasi biota tersebut. Menurut Reeves et al. (2000), habitat pesut air tawar sangat mudah mengalami perubahan dan penurunan kualitasnya akibat pengaruh aktivitas manusia, sehingga akan berdampak pada penurunan populasinya karena terjadi kematian. Penurunan populasi pesut akibat berbagai faktor terutama penurunan kondisi habitatnya, dikhawatirkan akan menyebabkan kepunahan pesut.

Penelitian populasi dan penyebaran pesut di perairan Kalimantan Timur telah dilakukan oleh Kreb \& Budiono (2005) yang meliputi perairan Belayan, Kedang Rantau, Kedang Kepala, Kedang Pahu, Ratah, dan Danau Semayang. Berdasarkan pada hasil analisis dengan menggunakan mark-recapture analyses dengan metode Petersen's, diperoleh dugaan populasi pesut yang tersebar di perairan Kalimantan Timur sebanyak 70 ekor ( $C V=10 \%$; $\mathrm{CL}=59-79$ ), sedangkan berdasarkan pada metode penghitungan langsung, populasi pesut diperkirakan 67 ekor (Yayasan Konservasi Rasi, 2006). Populasi pesut terutama tersebar di sungai utama dari Muara Kaman (180 km dari muara) menuju Muara Benangak (375 km dari muara) termasuk Belayan, Kedang, Kedang Kepala, Kedang Pahu, Ratah, dan Danau Semayang. Namun, migrasi musiman dapat menyebabkan pesut bermigrasi sampai ke Data Bilang (sekitar $500 \mathrm{~km}$ ke arah hulu sungai) (www.kutaikartanegara.com/pesut.html./12 Januari 2008).

Sumber informasi lain menunjukkan bahwa bahwa populasi pesut Mahakam di Kalimanatan Timur diperkirakan kurang dari 50 ekor. Penurunan populasi pesut juga disebabkan oleh tingkat pencemaran yang tinggi dan padatnya aktivitas lalu lintas sungai (Antara News, 2006). Sedangkan tingkat kematian tertinggi disebabkan oleh terperangkap jaring yang dipasang nelayan untuk menangkap ikan (Smith et al., 2003). Kreb \& Budiono dalam Kreb (2004) mengatakan bahwa jumlah pesut yang terperangkap jaring selama tujuh tahun (1995 - 2001) mencapai 81\%, perburuan secara illegal $8 \%$ dan akibat tertabrak baling-baling kapal $5 \%$ dengan jumlah 38 ekor atau rata-rata terjadi kematian pesut akibat beberapa faktor tersebut 5 ekor per tahun. Kegiatan penelitian tentang aspek lingkungan habitat, penyebaran dan konservasi pesut Mahakam di daerah Kalimantan Timur telah dilakukan oleh beberapa peneliti seperti Anonimus (1999; 2002; 2004).

Populasi hewan ini terus menurun akibat habitatnya terganggu, terutama dengan semakin ramainya lalu lintas di perairan Sungai Mahakam seperti perahu motor dan speed boat yang merupakan alat transportasi masyarakat setempat, serta tingginya tingkat erosi dan pendangkalan sungai akibat pengelolaan hutan di sekitarnya. Kelestarian pesut Mahakam juga diperkirakan terancam akibat terbatasnya bahan makanan berupa udang dan ikan, karena bersaing dengan para nelayan di sepanjang Sungai Mahakam. Mengingat populasi pesut Mahakam yang dikuatirkan akan terus mengalami penurunan akibat berbagai faktor tersebut di atas, maka perlu dikembangkan program konservasi yang efektif dan berkesinambungan yang dilakukan oleh Pemerintah Daerah terhadap lumba-lumba air tawar yang merupakan biota satu-satunya terdapat di Indonesia.

Tulisan ini bertujuan untuk mempelajari penyebaran pesut (Orcaella brevirostris) di Kalimantan secara spasial dan mengetahui status pemanfaatan dan upaya pelestariannya.

\section{BAHAN DAN METODE}

Penelitian ini dilakukan di wilayah perairan Danau Semayang-Melintang, Muara Pela, dan Muara Kaman Propinsi Kalimantan Timur selama lima trip dengan masing-masing trip lima sampai tujuh hari yang berlangsung tahun 2004 - 2006. Metode penelitian yang digunakan adalah survei lapangan dan wawancara langsung dengan para nelayan, masyarakat, dan Dinas Perikanan, Dinas Perlindungan Hutan dan Pelestarian Alam. Materi wawancara meliputi frekuensi dan waktu pemunculan pesut (Orcaella brevirostris) di sekitar Sungai Mahakam. Sedangkan wawancara dengan instansi pemerintah daerah meliputi keberadaan jenis dan kondisi populasi pesut. Pengamatan pesut dilakukan dengan menggunakan teropong binokuler pada jarak antara 20 - 30 m dari pos rumah jaga dan dari perahu bermotor sebagai titik lokasi pengamatan. Untuk menghindari terganggu aktivitas pesut dan mempermudah pengamatan, pada saat pengamatan, mesin motor perahu dimatikan. Peralatan lainnya yang digunakan adalah kamera digital SLR dengan lensa minimum 300 mm untuk mendokumentasikan gambar pesut yang muncul pada saat pengamatan. Sedangkan posisi pengamatan diketahui dengan menggunakan GPS merk Garmin. Penggunaan alat ini diperlukan juga untuk mengetahui distribusi. Untuk mengetahui populasi pesut di daerah pengamatan dilakukan dengan menghitung secara langsung terhadap individu pesut yang teramati. Penghitungan langsung dilakukan oleh lima orang peneliti yang berada di atas perahu dengan posisi arah pengamatan berbeda. Kemudian hasil pengamatan dan 

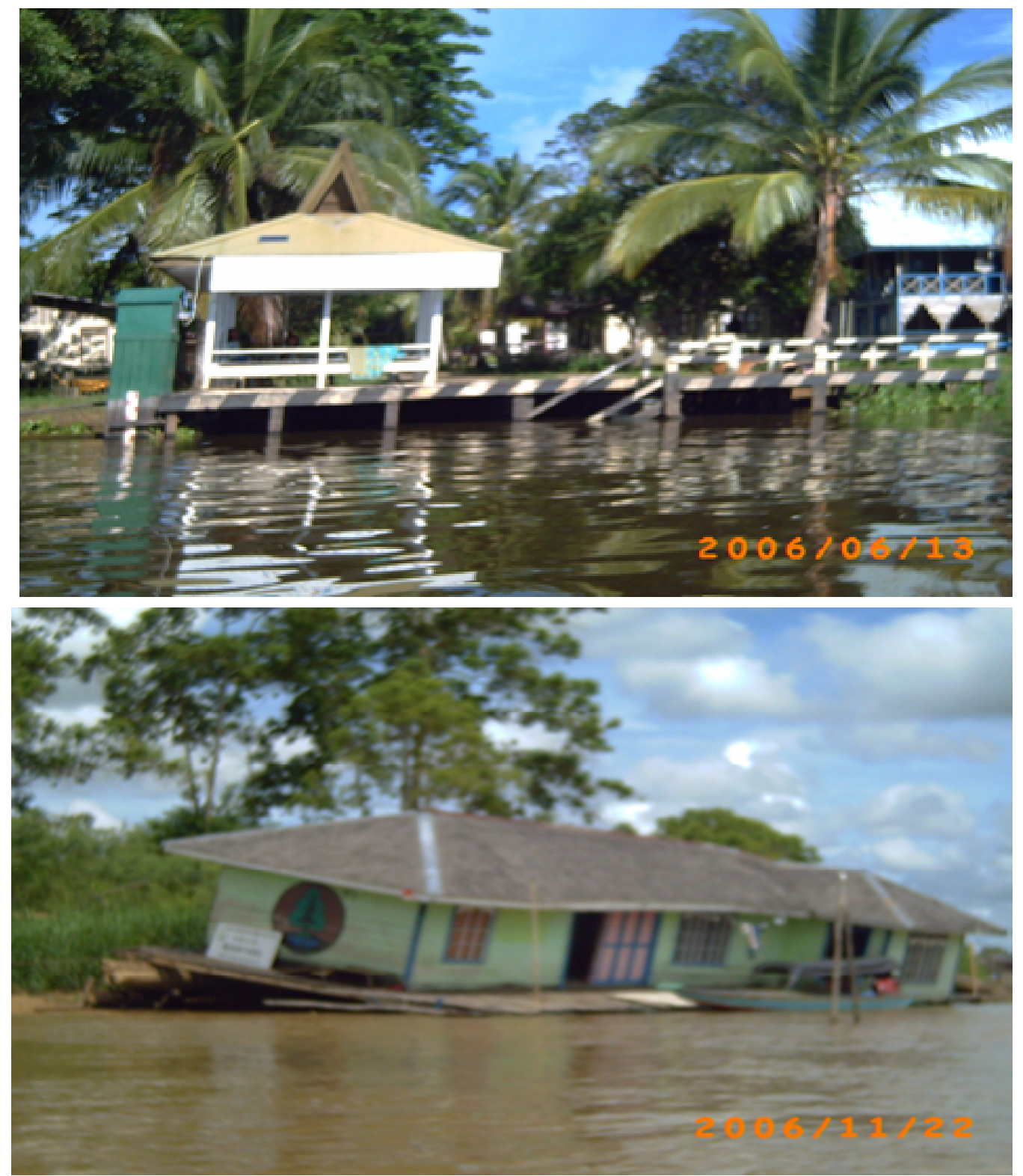

Gambar 1. Lokasi pemantauan pesut Mahakam (Orcaella brevirostris) di Sungai Pela dan di Balai Konservasi Sumber Daya Alam Muara Kaman.

Figure 1. Observation site of Mahakam's dolphin (Orcaella brevirostris) in Pela River and in Institute for Natural Resources Conservation, Muara Kaman.

penghitungan pesut dari masing-masing peneliti dibuat rata-rata. Lokasi pengamatan pesut dapat dilihat pada Gambar 1.

\section{HASIL DAN BAHASAN}

\section{Populasi dan Distribusi Pesut Mahakam}

Populasi pesut (O. brevirostris) di perairan Danau Semayang-Melintang, Muara Pela, dan Muara Kaman menurut hasil penghitungan langsung di lapangan tercatat sekitar 10 - 15 ekor yang tersebar dalam dua kelompok yaitu kelompok pesut yang dijumpai di Danau Semayang, Muara Pela, dan kelompok pesut di Muara Kaman. Kedua kelompok pesut ini diduga merupakan satu sub populasi. Pada tahun 1999 - 2000, diperkirakan jumlah populasi pesut yang terdapat di perairan Kalimantan Timur kurang dari 50 ekor (Reeves vide Kreb, 2004). Populasi pesut Mahakam diduga mengalami penurunan akibat berbagai faktor. Banyak faktor penyebab penurunan populasi pesut, antara lain pesut mati terjerat gill 
net nelayan, berkurangnya luasan habitat akibat pendangkalan dan ketersediaan ikan yang merupakan sumber makanan alami pesut di Sungai Mahakam. Beberapa faktor lainnya adalah tertabrak baling-baling kapal pengangkut kayu atau batu bara dan perahu motor yang digunakan untuk transportasi sungai, penurunan kualitas air sungai sebagai habitat pesut akibat buangan limbah industri dan bahan bakar minyak dari kapal atau perahu serta kemungkinan terperangkap dalam air yang dangkal pada saat musim kemarau. Pada periode tahun 1997 - 1999, Kreb (2004) mencatat 16 ekor pesut yang mati terjerat gill net (rata-rata lima ekor pesut per tahun). Lebih lanjut Kreb (2004) mengatakan bahwa beberapa faktor yang menyebabkan kematian pesut Mahakam terjerat jaring (66\%), perburuan (8\%), tertabrak kapal dan kematian dini (masing-masing 6\%), terperangkap di perairan dangkal (4\%), dan tersengat listrik dan pancing (masing-masing $2 \%$ ). Aktivitas penangkapan ikan di sekitar Sungai Danau Semayang-Melintang dapat dikatakan sebagai mata pencaharian utama bagi sebagian masyarakat setempat. Sedangkan alat tangkap yang digunakan jaring dasar. Pemasangan jaring dilakukan pada lokasi yang juga merupakan tempat bagi pesut untuk mencari makan.

Populasi lumba-lumba air tawar atau pesut di Sungai Mahakam dewasa ini semakin menurun dan perlu mendapat perhatian serius dari pemerintah setempat. Bahkan hasil pengamatan rata-rata pemunculan pesut di Sungai Mahakam menunjukkan nilai yang sama rendahnya dengan nilai yang dikatakan pada jenis lumba-lumba yang terancam punah di Sungai Yangtze, Lipotes vexilifer dan menunjukkan kritis keadaan populasi pesut (Sängertierkunde vide Kreb, 2004). Banyak faktor yang mengakibatkan berkurangnya luasan habitat pesut terutama besar laju sedimentasi, penutupan permukaan air oleh gulma air, dan terjadinya pembatasan gerak pesut oleh adanya pemasangan alat tangkap dan sarana lalu lintas sungai (terutama kapal pengangkut batu bara dan kayu). Sedangkan penurunan sumber makanan pesut terjadi akibat penangkapan ikan dan udang yang intensif dan tidak selektif serta introduksi ikan toman (Channa sp.) yang dapat menjadi pesaing pesut. Safrin (2001) mengatakan bahwa berkurangnya jumlah populasi pesut Mahakam berkaitan erat dengan rusaknya habitat tempat biota ini berkembang biak. Eksploitasi hutan yang dilakukan atas nama pembangunan telah menjadikan pesut terganggu dengan semakin dangkalnya wilayah Sungai Mahakam dan berubahnya kualitas air tempat biota ini hidup. Kebakaran hutan yang sering terjadi di provinsi ini telah turut menyumbang bagi kerusakkan lingkungan Sungai
Mahakam dengan meningkatnya sedimentasi lumpur, sehingga menyebabkan terjadinya pendangkalan di sepanjang Sungai Mahakam.

Menurut Ridway \& Harrison (1989), makanan pesut di alam terdiri atas beberapa jenis ikan dari famili Cyprinidae yaitu Barbichthys sp. (Barukung), Osteochilus sp. (repang), Thynnichthys vaillanti (kendia), Dangila cuviery (curing), Puntius brancides (salap), dan Melostoma cuviery (biawan). Makanan utama pesut berupa ikan bersirip lunak yang pada umumnya termasuk dalam kelompok ikan putihan. Berdasarkan pada pengamatan beberapa jenis ikan putihan yang dominan terdapat di Danau Semayang dan Danau Melintang adalah lalang (Hela oxygastroides), lais (Kryptopterus micronema), kendia, puyau luncup (Osteochilus triporos), dan repang (Osteochilus kappenii) (Nasution et al., 2008). Ikan-ikan putihan (ikan air putih) adalah ikan yang sebagian besar hidupnya dihabiskan di perairan yang airnya putih. Perairan yang tergolong perairan air putih (white waters) adalah perairan anak sungai utama dan perairan sungai utama serta perairan-perairan danau yang bukan danau banjiran. Ruas anak sungai utama ini juga digunakan untuk mencari makan baik oleh ikan dewasa atau sebagian individu ikan yang muda terutama pada bagian tepi (Hartoto, 2004). Selain itu, pesut juga memakan udang (Ridgway \& Harrison, 1989). Sedangkan rata-rata natalitas dan rata-rata mortalitas per tahun nilainya relatif sama, masingmasing 13,6 dan 11,4\%. Pada kondisi ini dan dengan memperhitungkan faktor lainnya yang diolah dalam program Vortex, Kreb (2004) mengatakan peluang populasi pesut bertahan tanpa ada upaya pelestariannya berkisar 1 - 4\%. Hal ini perlu mendapat perhatian segenap stakeholders terutama lembaga yang berkompeten untuk mempertahankan kelestarian pesut Mahakam.

Pesut Mahakam tersebar hampir di seluruh perairan Kalimantan Timur seperti di Teluk Balik Papan dan Sungai Mahakam. Berdasarkan pada hasil pengamatan, populasi pesut terkonsentrasi di Sungai Muara Pela yang berhubungan dengan perairan Danau Semayang-Melintang dan Muara Kaman. Di samping itu, kelompok pesut juga terdapat di perairan Muara Pahu (Kreb, 2004). Menurut informasi dari masyarakat setempat, pesut sering muncul di Sungai Mahakam antara Muara Kaman, perairan Batu Bumbun sampai Muara Alok, Sungai Pela Besar, dan Sungai Pela Kecil, Danau Semayang terutama dekat Muara Sungai Pela Kecil dan Sungai Pela Besar. Pesut juga dijumpai di Danau Melintang terutama di Muara Sungai Melintang atau pertemuan antara Danau Melintang, Sungai Melintang, dan Danau Semayang. Masyarakat juga 


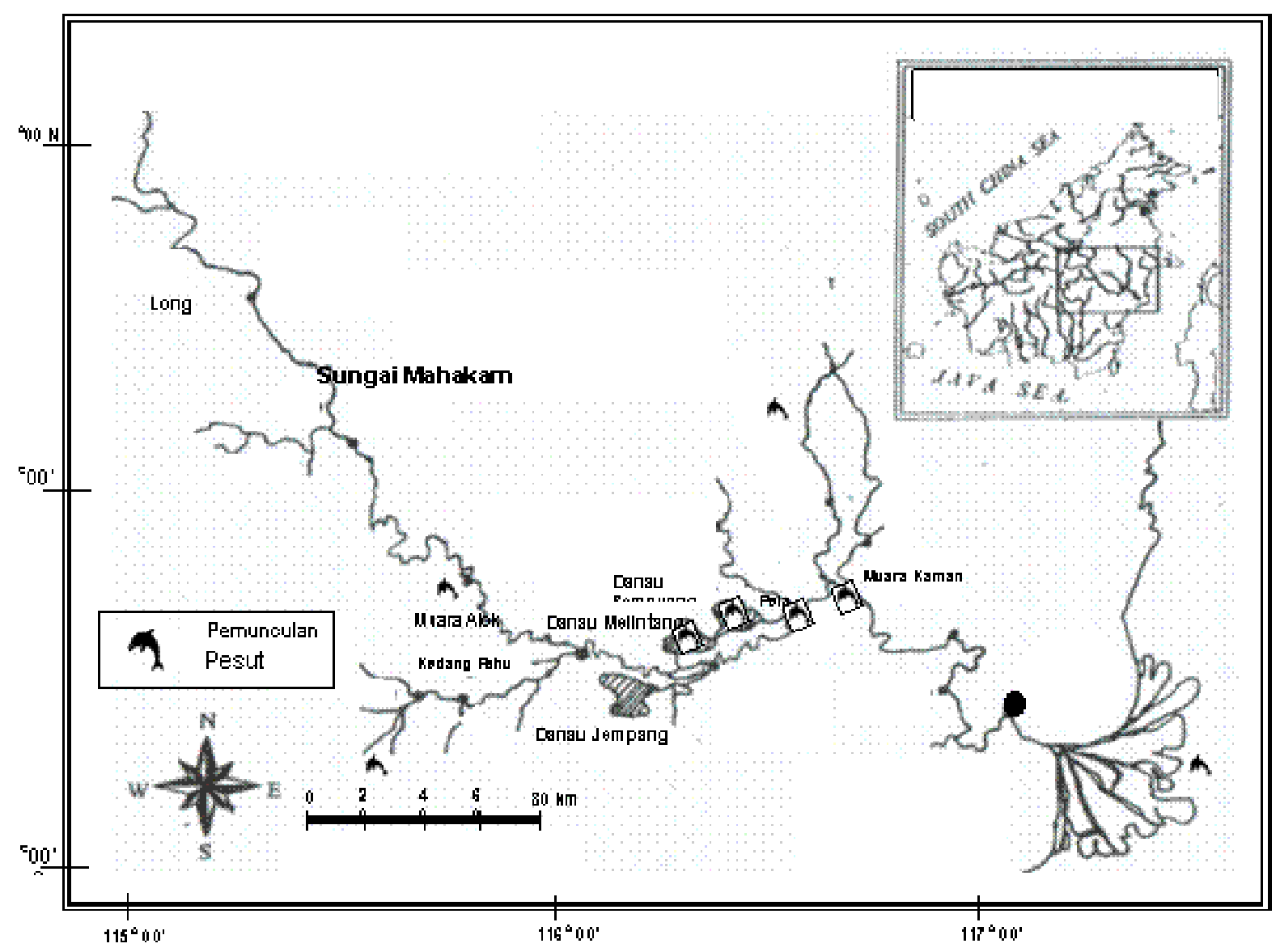

Gambar 2. Daerah penyebaran spasial pesut (Orcaella brevirostris) di Sungai Mahakam, Kalimantan Timur.

Figure 2. Spasial distribution of freshwater dolphin (Orcaella brevirostris) in Mahakam River, East Kalimantan.

Keterangan/Remarks:

: Pemunculan pesut terlihat pada survei/Appearing of freshwater dolphin observed during
survey
: Pemunculan pesut menurut Kreb (2004) dan nelayan lokal/Appearing of freshwater dolphin
according Kreb (2004) and fishers

menjumpai pesut di Danau Jempang pada pertemuan antara Sungai Batu Bumbun dan Sungai Mahakam. Penyebaran pesut berkaitan dengan ketersediaan ikthiofauna sebagai pakan pesut pada daerah tertentu seperti di Muara Kaman dan Danau Semayang sehingga daerah ini dapat dikatakan sebagai habitat mencari makan (feeding area). Daerah Muara Pela dan sekitarnya merupakan daerah bermain atau disebut juga roaming area. Pada waktu musim kemarau, kelompok pesut diduga mencari tempat yang lebih dalam dengan menuju ke Sungai Mahakam, karena kondisi air di Danau Semayang-Melintang makin dangkal. Ikan yang menjadi makanan pesut tidak bertahan hidup pada perairan danau yang suhu meningkat saat musim kemarau sehingga kelompok pesut bermigrasi ke sungai yang kondisi perairan lebih dalam daripada di perairan danau.

Namun, migrasi pesut kadang-kadang terhalang oleh keadaan lalu lintas air seperti perahu motor dan speed boat sehingga terpaksa kembali ke danau. Sementara itu, kondisi perairan di danau semakin lama semakin surut, hal ini dapat menyebabkan pesut terperangkap. Keadaan ini apabila secara kebetulan diketahui oleh masyarakat setempat, dapat menyelamatkan pesut tersebut, tetapi sebaliknya jika masyarakat tidak ada yang mengetahui, dapat dipastikan pesut tersebut akan mengalami kematian. Daerah penyebaran pesut di Kalimantan Timur dapat dilihat pada Gambar 2. Menurut Kreb (2004), 
kelompok pesut berada di jalur utama Sungai Mahakam berkisar antara 180 - 480 km ke arah hulu, juga termasuk beberapa anak sungai dan danau tergantung pada musim. Namun, pesut kadangkadang bergerak jauh ke hilir dan hulu sepanjang 80 dan 600 km. Penyebaran pesut dapat berubah sesuai musim dan dipengaruhi oleh ketinggian permukaan air serta ketersediaan makanan yang bervariasi (Anonimus, 2002).

\section{Pemunculan Pesut}

Informasi tentang kelimpahan ikan dan pemunculan pesut Mahakam secara harian dapat menggambarkan aktivitas pesut tersebut pada suatu daerah. Adanya kaitan antara kelimpahan ikan dengan pemunculan pesut Mahakam mengindikasikan aktivitas pesut mencari makan, sehingga daerah tersebut dapat diduga sebagai feeding area. Pemunculan pesut di Danau Semayang selama pengamatan bulan Nopember tercantum pada Tabel 1. Sedangkan pada bulan April di saat air rendah tidak dijumpai. Berdasarkan pada hasil pengamatan, pesut muncul pada saat sedang mencari makan.
Lokasi di sekitar muara sungai merupakan tempat mencari makan yang baik pesut. Muara sungai merupakan daerah yang sering mengalami upwelling atau perputaran air akibat pertemuan arus yang berlawanan. Proses upwelling akan mengangkat nutrien-nutrien di dasar perairan ke permukaan. Pada saat tersebut, banyak ikan-ikan sungai terutama kelompok ikan putihan dapat memanfaatkan plankton sebagai makanan. Plankton menjadi subur, karena adanya nutrien yang disebabkan oleh proses upwelling. Dengan demikian dapat dikatakan bahwa feeding area atau tempat mencari makan ikan-ikan sungai adalah juga sebagai feeding area bagi pesut. Pernyataan ini diperkuat oleh keterangan masyarakat setempat dengan seringnya melihat pesut Mahakam muncul di sekitar muara Sungai Pela atau pada saat pesut melakukan perjalanan hilir mudik dari danau melalui Sungai Pela besar dan kecil menuju Sungai Mahakam. Tabel 1 memperlihatkan bahwa waktu pemunculan pesut terjadi pada pagi, siang, dan sore hari antara jam 05.00 - 11.00 dan 14.00 - 17.30. Pemunculan pesut Mahakam (jumlah dan frekuensi) dapat dijadikan petunjuk tibanya musim dan lokasi penangkapan ikan (Kreb, komunikasi pribadi, 2006).

Tabel 1. Posisi, waktu, dan jumlah pemunculan pesut Mahakam (O. brevirostris) di Danau Semayang, Muara Pela, dan Muara Kaman, bulan Oktober 2005 dan Nopember 2006 Table 1. Position, time, and frequency of freshwater dolphin (O. brevirostris) appearence in Semayang Lake, Muara Pela, and Muara Kaman, October 2005 and November 2006

\begin{tabular}{|c|c|c|c|}
\hline Posisi/Positions & Lokasi/Locations & Waktu/Times (WITA) & Frekuensi/Frequencies \\
\hline $\begin{array}{l}\text { S: } 00^{\circ} 09^{\prime} 23.7^{\prime \prime} \\
E: 116^{\circ} 42^{\prime} 49.6^{\prime \prime}\end{array}$ & Muara Kaman & $\begin{array}{l}05.30 \\
11.30\end{array}$ & $\begin{array}{l}3 \\
3\end{array}$ \\
\hline $\begin{array}{l}\text { S: } 00^{\circ} 09^{\prime} 28,7^{\prime \prime} \\
\text { E: } 116^{\circ} 42^{\prime} 48,9^{\prime \prime}\end{array}$ & Muara Kaman & 16.30 & 5 \\
\hline $\begin{array}{l}\text { S: } 00^{\circ} 03^{\prime} 35.7^{\prime \prime} \\
\text { E: } 116^{\circ} 42^{\prime} 46.7^{\prime \prime}\end{array}$ & Muara Kaman & 17.20 & 4 \\
\hline Rata-rata/Average & & & 5 \\
\hline $\begin{array}{l}\text { S: } 00^{\circ} 14^{\prime} 50.9^{\prime \prime} \\
\text { E: } 116^{\circ} 31^{\prime} 55.2^{\prime \prime}\end{array}$ & D. Semayang & 19.20 & 5 \\
\hline $\begin{array}{l}\text { S: } 00^{\circ} 14^{\prime} 09,9^{\prime \prime} \\
\text { E: } 116^{\circ} 33^{\prime} 55,2^{\prime \prime}\end{array}$ & M. Pela & $\begin{array}{l}08.05 \\
14.00\end{array}$ & $\begin{array}{l}6 \\
4\end{array}$ \\
\hline $\begin{array}{l}\text { S: } 00^{\circ} 14^{\prime} 09,16^{\prime \prime} \\
\text { E: } 116^{\circ} 33^{\prime} 13,8^{\prime \prime}\end{array}$ & M. Pela & $\begin{array}{l}15.50 \\
16.05\end{array}$ & $\begin{array}{c}6 \\
10\end{array}$ \\
\hline $\begin{array}{l}\text { S: } 00^{\circ} 14^{\prime} 17,9^{\prime \prime} \\
\text { E: } 116^{\circ} 33^{\prime} 14,5^{\prime \prime}\end{array}$ & M. Pela & $\begin{array}{l}08.10 \\
08.30\end{array}$ & $\begin{array}{l}7 \\
3\end{array}$ \\
\hline $\begin{array}{l}\text { S: } 00^{\circ} 14^{\prime} 25,2^{\prime \prime} \\
\text { E: } 116^{\circ} 33^{\prime} 03,0,2^{\prime \prime}\end{array}$ & M. Pela & $\begin{array}{l}14.00 \\
16.30\end{array}$ & $\begin{array}{l}4 \\
5\end{array}$ \\
\hline Rata-rata/Average & & & 10 \\
\hline
\end{tabular}

Pesut hidup berkelompok, dalam satu kelompok terdiri atas 3 - 10 ekor. Pada saat berenang yang terlihat di permukaan air hanya sebagian tubuh, kepala, dan sirip punggung. Kepala muncul ke permukaan untuk mengambil nafas setiap 1,5 menit, sementara ekornya tidak terlihat (Anonimus, 1984). Apabila dilihat dari waktu pemunculan pesut, mamalia ini bergerak pada pagi hari antara jam 05.30 - 11.30 dan sore hari antara jam 16.30 - 19.00. Waktu dan posisi pemunculan pesut ini dapat dijadikan acuan 
untuk kegiatan ekowisata. Pemunculan pesut menjadi terganggu jika ada speed boat sebagai alat angkutan sungai melewati habitatnya. Kreb \& Rahadi dalam Kreb (2004) mengatakan bahwa lumba-lumba sungai menjadi sangat jarang muncul dengan kehadiran kapal motor (<40 stk), speedboats (40 - 200 stk) dan kapal penarik ponton (>1.000 stk). Lebih lanjut dikatakan bahwa lumba-lumba sungai akan bereaksi pada jarak maksimum $250 \mathrm{~m}$ sebelum dan $300 \mathrm{~m}$ setelah speedboat berlalu.

Untuk menjumpai pemunculan pesut di dua lokasi tersebut lebih mudah pada saat kondisi perairan rendah atau saat musim kemarau.

\section{Status Pemanfaatan}

Peran suatu spesies dalam upaya konservasi ditinjau dari sudut pandang biologis, sosio ekonomi, dan politik adalah beragam. Hal ini tergantung dari sudut pandang dan kepentingan yang melatar belakanginya. Meffe et al. (1997) menggolongkan suatu spesies ke dalam enam katagori, yaitu spesies pokok (keystone species), spesies indikator (indicator species), spesies payung (umbrella species), spesies bendera (flagship species), spesies rawan punah (vulnerable species), dan spesies ekonomis penting (economically important species). Pesut Mahakam termasuk dalam katagori spesies bendera (flagship species), karena spesies yang termasuk ke dalam katagori ini menurut Meffe et al. (1997), adalah spesies yang mampu menghubungkan masyarakat pada hal positif (mampu menimbulkan rasa kebanggaan) secara emosional yang akan menimbulkan suatu reaksi perlindungan yang kuat terhadap spesies tersebut. Masyarakat setempat pada umumnya telah menyadari arti pelestarian pesut dengan memperlakukan secara wajar dan sama sekali tidak ingin membunuh jika tertangkap atau terperangkap jaring nelayan. Menganggap bahwa pesut sebagai penolong jika terjadi peristiwa kecelakaan di sungai, misalnya ada nelayan yang tenggelam, maka pesut akan mendekat dan berusaha untuk mendorong ke permukaan air.

Selain itu, masyarakat Kabupaten Kutai Kartanegara, khususnya menghormati keberadaan pesut secara tradisional. Hal ini dibuktikan dengan menjadikan pesut sebagai lambang daerah Kabupaten Kutai Kartanegara dan merupakan kebanggaan daerah tersebut. Lembaga pemerintah yang berwenang mengawasi pesut di Sungai Mahakam adalah Balai Konservasi Sumber Daya Alam yang berada di bawah Departemen Kehutanan dan lembaga swadaya masyarakat yang peduli pesut yaitu Yayasan Konservasi Rare Aquatic Species of Indonesia.

Salah satu daerah suaka perikanan yang terdapat di Kabupaten Kutai Kartanegara, Propinsi Kalimantan Timur adalah suaka perikanan Danau Loakang yang merupakan danau banjiran. Sejak 1970-an, danau banjiran ini telah dikelola sebagai suaka perikanan untuk memasok atau mensuplai indukan dan anakan ikan untuk kelestarian perikanan tangkap dan makanan alami bagi pesut Mahakam (Hartoto, 2000). Pengelolaan suaka perikanan Danau Loakang telah dilaksanakan oleh penduduk lokal dan kondisi sampai dengan saat ini baik. Nelayan lokal menganggap keberadaan pesut di suatu tempat pada waktu tertentu mengindikasikan bahwa tempat tersebut merupakan sumber ikan dan tibanya musim penangkapan. Di samping itu, pesut Mahakam berpotensi sebagai pengembangan wisata pesut yang secara langsung dapat meningkatkan pendapatan masyarakat sekitar. Pesut dapat dijadikan sebagai indikator spesies yang menunjukkan bahwa kemungkinan komunitas ikthiofauna dalam keadaan baik.

\section{Upaya Konservasi}

Berdasarkan pada Surat Keputusan Menteri Pertanian No.35/Kpts/Um/1975, tertanggal 29 Januari 1975 bahwa status pesut Mahakam sebagai satwa yang dilindungi, karena dikuatirkan populasinya akan terus mengalami penurunan akibat terdegradasinya habitat biota tersebut. Berkaitan dengan hal ini, disarankan bahwa wilayah perairan habitat pesut serta hutan di sekitar perairan tersebut dapat dijadikan suaka margasatwa. Selain untuk melestarikan pesut, suaka margasatwa dapat juga ditujukan untuk memberikan tempat hidup dan berlindung bagi satwa langka lain maupun berbagai jenis ikan air tawar sebagai makanan utama pesut Mahakam.

Upaya konservasi untuk pesut Mahakam dapat juga dilakukan antara lain melalui ekowisata (ekoturisme) atau wisata air. Ekowisata adalah suatu kegiatan manusia di alam yang mempunyai fungsi meningkatkan pemahaman tentang alam, mengembangkan ekonomi lokal tanpa menimbulkan dampak yang merusak dan pada akhirnya diharapkan dapat meningkatkan retribusi. Pada prinsipnya, ada tiga tahap perkembangan ekowisata akuatik, yaitu pertama tahap bagaimana hidup di alam (in nature stage), kedua tahap tentang alam (about nature stage), dan ketiga tahap kontribusi untuk alam (for nature stage). Berkaitan dengan hal ini, salah satu informasi yang penting sebagai dasar pengembangan ekoturisme di perairan darat adalah informasi 
mengenai fenologi hewan dan tumbuhan, terutama tentang bilamana terjadi aktivitas dan fenomena khusus yang mungkin menarik bagi wisatawan. Data tentang pemunculan pesut Mahakam dan aktivitas ikan yang menjadi mangsa sangat bermanfaat dalam penyusunan rencana kunjungan wisata. Sedangkan lokasi-lokasi dan waktu untuk menikmati pemandangan gerak dan tingkah laku dari pesut Mahakam kaitannya dengan ekowisata yaitu di Danau Semayang, Danau Melintang, Sungai Pela, dan Sungai Muara Kaman pada pagi hari antara jam 05.30 - 11.30 dan sore hari antara jam 16.30 - 19.00 (Tabel 1).

Di Kalimantan Timur, terdapat daerah yang disukai wisatawan asing maupun domestik dengan melakukan penjelajahan alam atau petualangan. Daerah tersebut adalah Tanjung Isuy yang masyarakatnya memiliki kebudayaan dan adat istiadat Dayak asli terutama Suku Dayak Benua dan Cagar Alam Kesik Luwai yang memiliki anggrek hitam yang khas (Wirawan \& Toga, 1984). Kedua lokasi tersebut terdapat dalam satu jalur lalu lintas yang sama, jalur lalu lintas yang dilalui merupakan wilayah habitat pesut Mahakam. Peningkatan lahan pelestarian pesut sebagai obyek wisata dapat menjadi satu paket wisata, sehingga paket wisata akan memiliki daya tarik tersendiri. Konservasi pesut Mahakam merupakan bagian tak terpisahkan dari sistem pengelolaan sumber daya perikanan (sumber daya ikan yang menjadi makanan) di Sungai Mahakam. Untuk menjamin ketersediaan ikan putihan sebagai faktor penentu kelangsungan hidup pesut Mahakam, perlu dikembangkan habitat kantong ikan dalam bentuk suaka perikanan. Suaka perikanan adalah suatu perairan, baik merupakan perairan umum daratan atau perairan bahari yang ikan tersebut tidak boleh ditangkap (Utomo et al., 2001). Sedangkan menurut Undang-Undang No.31 tahun 2004 tentang Perikanan, suaka perikanan atau konservasi sumber daya ikan adalah upaya perlindungan, pelestarian, dan pemanfaatan sumber daya ikan, termasuk ekosistem, jenis, dan genetik untuk menjamin keberadaan, ketersediaan, dan kesinambungan dengan tetap memelihara dan meningkatkan kualitas nilai dan keanekaragaman sumber daya ikan. Suaka perikanan merupakan salah satu lokasi yang digunakan dalam upaya pengelolaan sumber daya perikanan perairan umum untuk pelestarian plasma nutfah dan peningkatan produksi. Untuk itu diperlukan suaka perikanan yang memenuhi persyaratan agar dapat berfungsi sebagai tempat perlindungan sumber daya ikan dan dapat menghasilkan benih secara alami ke daerah sekitar (Hartoto videAnonimus, 1996).
Suaka perikanan memiliki tujuan pengelolaan untuk menjamin kelestarian sumber daya ikan melalui penerapan prinsip-prinsip pengelolaan berkelanjutan (Rommy dalam Nikijuluw et al., 2007). Dengan demikian, suaka perikanan ini selain berfungsi sebagai tempat mencari makan pesut Mahakam, juga berperan sebagai sumber pasokan alamiah anakan dan indukan ikan yang dapat memperkuat stok ikan yang dapat ditangkap oleh nelayan. Lokasi-lokasi yang disarankan untuk dikembangkan dan dipertahankan pengelolaannya sebagai suaka perikanan antara lain Danau Loakang dan Danau Batu Bumbun yang terletak di sekitar Sungai Pela dan Sungai Muara Kaman. Kedua lokasi tersebut letaknya berhubungan dengan Danau Semayang-Melintang, Sungai Muara Pela, Sungai Muara Kaman yang merupakan habitat pesut Mahakam. Kedua lokasi tersebut memenuhi syarat sebagai daerah suaka perikanan karena memiliki kedalaman cukup, tidak mengalami kekeringan pada saat musim kemarau, banyak tersedia pakan alami (plankton, perifiton, serangga air, dan lain-lainnya), sehingga ikan dapat tumbuh dan berkembang biak dengan baik, terdapat vegetasi hutan rawa dan tanaman air di sekitar sebagai tempat mencari makan, pemijahan, dan asuhan. Memiliki fluktuasi air yang besar antara musim kemarau dan penghujan (2 - $4 \mathrm{~m}$ ), sehingga pada saat musim penghujan, ikan dapat dengan mudah menyebar ke daerah hutan rawa untuk memijah, sedangkan pada saat kemarau kembali ke suaka. Suaka berhubungan dengan perairan lainnya, tidak tertutup, terdapat jalur migrasi berupa kanal, sehingga benih ikan dapat menyebar ke perairan sekitarnya. Dalam pengelolaan suaka, ada partisipasi masyarakat setempat. Sedangkan luasan yang ideal pada tipe suaka danau rawa (oxbow lake), untuk ikan putihan dan ikan rawa adalah 20 ha (Utomo et al., 2001).

\section{KESIMPULAN}

1. Distribusi pesut Mahakam (Orcaella brevirostris) terkonsentrasi di Sungai Muara Pela yang berhubungan dengan perairan Danau SemayangMelintang dan Muara Kaman, dengan populasi berkisar 10 - 15 ekor. Di samping itu, kelompok pesut juga terdapat di perairan Muara Pahu. Distribusi pesut berhubungan dengan ketersediaan ikthiofauna sebagai pakan utama. Daerah Muara Kaman dan Danau Semayang merupakan habitat pesut untuk mencari makan (feeding area), sedangkan Muara Pela merupakan daerah bermain (roaming area). 
2. Lokasi dan waktu pemunculan pesut dapat dijadikan acuan bagi kegiatan ekowisata di Danau Semayang-Sungai Mahakam. Pesut Mahakam termasuk dalam katagori spesies bendera (flagship species), karena spesies yang termasuk ke dalam katagori ini adalah spesies yang mampu menimbulkan rasa kebanggaan secara emosional yang akan menimbulkan suatu reaksi perlindungan yang kuat terhadap spesies tersebut.

3. Untuk menjamin ketersediaan ikan putihan sebagai faktor penentu keberlangsungan hidup pesut Mahakam perlu dikembangkan habitat kantong ikan dalam bentuk suaka perikanan yang selain berfungsi sebagai tempat mencari makan pesut Mahakam, juga berperan sebagai sumber pasokan alamiah anakan dan indukan ikan yang dapat mempertahankan stok ikan yang dapat ditangkap oleh nelayan.

\section{PERSANTUNAN}

Kegiatan dari hasil riset inventarisasi mamalia air, T. A. 2004-2006, di Pusat Riset Perikanan Tangkap, Ancol-Jakarta.

\section{DAFTAR PUSTAKA}

Anonimus. 1984. Usaha pelestarian pesut Sungai Mahakam (Orcaella brevirostris, Gray 1866). PT. Pembangunan Jaya Proyek Ancol Gelanggang Samudera Jaya Ancol. 10 hal.

Anonimus. 1996. Pemulihan dan pelestarian ikan semah (Tor douronensis) melalui penetapan reservat di Kabupaten Sarolangun Bangko, Jambi. Pusat Penelitian dan Pengembangan Limnlogi. Lembaga IImu Pengetahuan Indonesia.Dinas Perikanan Tingkat I Propinsi Jambi. p.1-6.

Anonimus. 1999. Observation on the occurrence of the Irrawady Dolphin, Orcaella brevirostris, in the Mahakam River, East kalimantan, Indonesia. Zeitschrift fiir Saugetierkunde. 64. pp. 54-58.

Anonimus. 2002. Density and abundance of the Irrawaddy dolphin, Orcaella brevirostris in the Mahakam River of East Kalimantan, Indonesia: A comparison of survey techniques. The Raffles Bulletin of Zoology. Supplement 10. pp. 85-95.

Anonimus. 2004. Abundance of freshwater Irrawaddy dolphins in the Mahakam River in East Kalaimantan, Indonesia, based on mark recapture analysis of photo identified individuals. Journal of Cetacean Research and Management. $22 \mathrm{p}$.
Antara News. 2006. Populasi pesut Mahakam di perkirakan kurang dari 50 ekor. Surat Kabar Samarinda. 24 April 2006.

Hartoto, D. I. 2000. An overview of some limnological parameters and management status of fishery reserves in Central Kalimantan. Report of the Suwa Hydrobiological Station Shinshu University. Japan. No.12: 49-74.

Kreb, D. \& Budiono. 2004. Conservation management of small core areas: Key to survival of a critically endangered population of riverine Irrawaddy Dolphins in Borneo. Oryx. 23 pp.

Kreb, D. \& K. D. Rahadi. 2004. Living under an aquatic freeway: Effects of boat on Irrawaddy Dolphins (Orcaella brevirostris) in a coastal and riverine environment in Indonesia. Aquatic Mammals. $22 \mathrm{p}$.

Kreb, D. 2004. Facultative River Dolphins. Conservation and Social Ecology of Freshwater and Coastal Irrawaddy Dolphins in Indonesia. Institute for Biodiversity and Ecosystem Dynamic. Copyright@ D. Kreb. 230 pp.

Kreb, D. \& Budiono. 2005. Conservation management of small core areas: Key to survival of a critically endangered population of Irrawady river dolphins Orcaella brevirostris in Indonesia. Oryx 39 (2). 111.

Meffe, G. K, C. R. Carroll, \& Contributors. 1997. Principles of Conservation Biology. Second Edition. Sinauer Associates. Inc. Publishers Sunderland. Massachusetts. USA. 729 pp.

Nasution, S. H, D. Oktaviani, Dharmadi, \& D. I. Hartoto. 2008. Komunitas ikan dan faktor kondisi beberapa ikan putihan di Sungai Muara Kaman dan Danau Semayang. LIMNOTEK. Lembaga IImu Pengetahuan Indonesia. Vol.XV. (1). p. 10-21.

Nikijuluw, V. P. H., J. Poeloe, M. N. Dahlan, \& C. B. Purba. 2007. Sistem Alternatif Manajemen Sumber Daya Kelautan dan Perikanan. Pusat Riset Perikanan Tangkap. Badan Riset Kelautan dan Perikanan. Departemen Kelautan dan Perikanan. Jakarta. 178 p.

Smith, B. D., I. Beasley, \& D. Kreb. 2003. Marked decline in population of Irrawady Dolphins. Oryx 37 (4). 401 pp. 
Wirawan, N. \& Toga, S. 1984. Potensi pelestarian pesut dalam pembangunan Kalimantan Timur. Makalah Seminar Konservasi dan Biologi Pesut Mahakam. Kutai Kertanegara. Kalimantan Timur (tidak dipublikasikan). 6 p.

www.kutaikartanegara.com/pesut.html. Sekilas tentang pesut. members.tripod.com/yk_rasi/ ykrasi_activity.html. YK. RASI ACTIVITIES. 12 Januari 2008.
Utomo, A. D., Asyari, \& S. Nurdawati. 2001. Peranan suaka perikanan dalam peningkatan produksi dan pelestarian sumber daya perikanan perairan umum (Studi kasus di suaka perikanan Suak Buaya, Lubuk Lampam, Kabupaten Ogan Komering Ilir, Sumatera Selatan). Jurnal Penelitian Perikanan Indonesia. Vol.7 No.1. hal.1-9. 